\title{
STAGE-DisCHARGE RELATIONSHIPS OF DRAWDOWN PLATES FOR DENITRIFYING WOODCHIP BIOREACTORS
}

\author{
Bryan M. Maxwell1,**, Richard A. Cooke², Reid D. Christianson'1, Laura E. Christianson ${ }^{1}$ \\ ${ }^{1}$ Department of Crop Sciences, University of Illinois Urbana-Champaign, Urbana, Illinois, USA. \\ ${ }^{2}$ Department of Agricultural and Biological Engineering, University of Illinois Urbana-Champaign, Urbana, Illinois, USA. \\ ${ }^{3}$ Correspondence: bmmaxwel@illinois.edu.
}

\section{HighLIGHTS}

- Drawdown plates can prevent prolonged saturation in denitrifying woodchip bioreactors.

- Contraction coefficients for the orifice equation ranged from 0.74 to 0.76 .

- Drawdown orifice should be sized appropriately to avoid interfering with design flow rates.

- Established stage-discharge relationships for drawdown orifice improve accuracy of flow monitoring.

ABSTRACT. Denitrifying woodchip bioreactors are a conservation drainage practice used to reduce nitrate loads in tile drainage water from field crops. Prolonged saturation in the woodchip media under no flow or low flow conditions can result in the production of hydrogen sulfide and methane. The US Department of Agriculture Natural Resources Conservation Service's (NRCS) Conservation Practice Standard for denitrifying bioreactors recommends a low-level orifice at the bioreactor outlet to drain the woodchip media within $48 \mathrm{~h}$ to prevent prolonged stagnation. This study determined stagedischarge relationships for three drawdown configurations in an AgriDrain water level control structure $115.2 \mathrm{~cm}$ nominal tile size) to improve accuracy of estimating flow in field bioreactors. Tested drawdown configurations consisted of a custommade inverted-v orifice plate currently used by the NRCS (3.6 $\mathrm{cm}^{2}$ orifice area); and a 2 and an $8 \mathrm{~mm}$ gap between the base of the structure and the bottom stop log (2.6 and $12.3 \mathrm{~cm}^{2}$ orifice area, respectively). The stage-discharge relationship for all three orifices was accurately described by the orifice flow equation $\left(R^{2}>0.99\right)$. Stage-discharge relationship for the inverted-v drawdown plate in combination with a stainless steel-edged v-notch weir was the sum of their respective stagedischarge relationships for orifice flow and flow over the weir. Contraction coefficients for the inverted-v, $2 \mathrm{~mm}$ gap, and 8 mm gap configurations were 0.74, 0.74, and 0.76, respectively. The stage-discharge relationships for the inverted-v, $2 \mathrm{~mm}$ gap, and $8 \mathrm{~mm}$ gap configurations were $Q=3.26^{*} A^{*} h^{0.5}, Q=3.29 * A^{*} h^{0.5}$, and $Q=3.38^{*} A^{*} h^{0.5}$, respectively, where $Q$ is in $\mathrm{m}^{3} \mathrm{~s}^{-1}$, A is the orifice area in $\mathrm{m}^{2}$, and $h$ is the water head differential in meters.

Keywords. Denitrifying bioreactor, Drawdown plate, Flow monitoring, NRCS, Prolonged saturation.

W oodchip bioreactors (or denitrifying bioreactors) are an approved conservation drainage practice (USDA NRCS, 2020) that reduces nitrate loads in tile drainage by routing tile drainage water to a denitrifying woodchip bed. Nitrate load in the woodchip bioreactor is reduced by maintaining a saturated media profile with sufficient hydraulic residence time (HRT) that anaerobic processes (i.e., denitrification) occur (Schipper et al., 2010). While woodchip bioreactors with sufficiently long HRT can achieve the desired outcome of reducing the nitrate load, excessively long HRT can produce

\footnotetext{
(c) (1) $\odot$ The authors have paid for open access for this article. This work is licensed under a Creative Commons AttributionNonCommercial-NoDerivatives 4.0 International License https://creative commons.org/licenses/by-nc-nd/4.0/

Submitted for review on 13 April 2021 as manuscript number NRES 14633; approved for publication as a Research Brief by the Natural Resources \& Environmental Systems of ASABE on 16 September 2021.
}

undesired compounds with negative environmental and health effects. Where sulfate is present in the water, sulfatereducing bacteria in woodchip bioreactors can produce hydrogen sulfide gas (Lepine et al., 2016) which is toxic in aquatic ecosystems (Kinsman-Costello et al., 2015) and has harmful human health effects. Under prolonged saturated conditions, woodchip bioreactors can become a source of methane (Warneke et al., 2011; Davis et al., 2019), a potent greenhouse gas, as microbes consume available carbon via methanogenesis. In some instances, strongly reducing conditions can lead to bioreactors becoming net sources of methyl mercury (Shih et al., 2011).

Bioreactors are typically designed with a target HRT such that tile drainage water is not completely denitrified during normal flows, avoiding the likelihood of hydrogen sulfide and methane formation. Under certain low flow conditions or dry periods without flow, prolonged saturated conditions with stagnant water can produce these gases. Stop logs at the 
bioreactor outlet can be manually lifted to fully drain the bioreactor, however doing so requires labor and time by the farmer and awareness of tile drainage flow at any given time. The US Department of Agriculture Natural Resources Conservation Service (USDA NRCS) Conservation Practice Standard (CPS) for denitrifying bioreactors recommends "a low-level orifice in the outlet water control structure to assure the media chamber drains in a maximum of $48 \mathrm{~h}$ during periods of low or no flow" (USDA NRCS, 2020). A drawdown plate, consisting of a low-level orifice in the control structure stop log, helps achieve the NRCS recommendation of draining the media within $48 \mathrm{~h}$. However, stage-discharge relationships for these low-level orifices placed in water level control structures are needed in order to accurately estimate flow through the water level control structure when drawdown configurations are used. Three drawdown configurations were tested in an AgriDrain water level control structure to establish stage-discharge relationships between water head differential across the plate and flow rates through the orifice. The objective of these experiments was to quantify stage-discharge relationships for several drawdown configurations such that flow through the water level control structures could be accurately estimated when using a drawdown feature.

\section{MATERIALS AND METHODS}

Experiments were performed in December 2020 at the Hydraulics Lab of the Department of Agricultural and Biological Engineering at University of Illinois Urbana-Champaign where stage-discharge relationships for flow through AgriDrain control structures have previously been established for several weir configurations (Chun and Cooke, 2008; Christianson et al., 2019). Flow rates were measured through an AgriDrain $15.2 \mathrm{~cm}$ (6 in. nominal tile diameter) inline water level control structure (as illustrated in Christianson et al., 2019), the most commonly used control structure for controlling water level in field bioreactors in the Midwest. Flow was provided by a constant head overflow tank. Flow rates through the control structure for a given drawdown configuration were measured by recording weight of water captured in a load cell downstream of the control structure over a given time interval. Load cell was calibrated prior to experiments by adding a known volume of water to the load cell, and calibration reconfirmed at end of experiment. Sample times were recorded to the nearest tenth of a second using a stopwatch. Sample intervals were at least $30 \mathrm{~s}$ in duration to minimize relative error due to manual time measurements. Water head difference between the upstream and downstream side of the stop logs was measured in clear stilling wells placed on the outside of the control structures. Stilling wells placed upstream and downstream of the stop logs were used to reduce water level fluctuations from small variations in flow when measuring water level, similar to methods used by Christianson et al. (2019). Upstream and downstream water level was measured to the nearest millimeter using measuring tape fixed to the side of the stilling wells. Flow through the structure was adjusted until water level in the stilling wells was stable, and then flow rate at each water level measured in triplicate.

Three different drawdown configurations were tested (fig. 1). Drawdown plates were made using standard stop log sizes manufactured by AgriDrain (Adair, Iowa). All drawdown plates were placed at the base of the control structure, with each plate $17.8 \mathrm{~cm}$ in height (standard 7 in. AgriDrain stop $\log$ ). The first plate tested was an inverted-v orifice which has been recommended for use as a "low-level orifice" (e.g., CPS 605) at bioreactors designed by the USDA
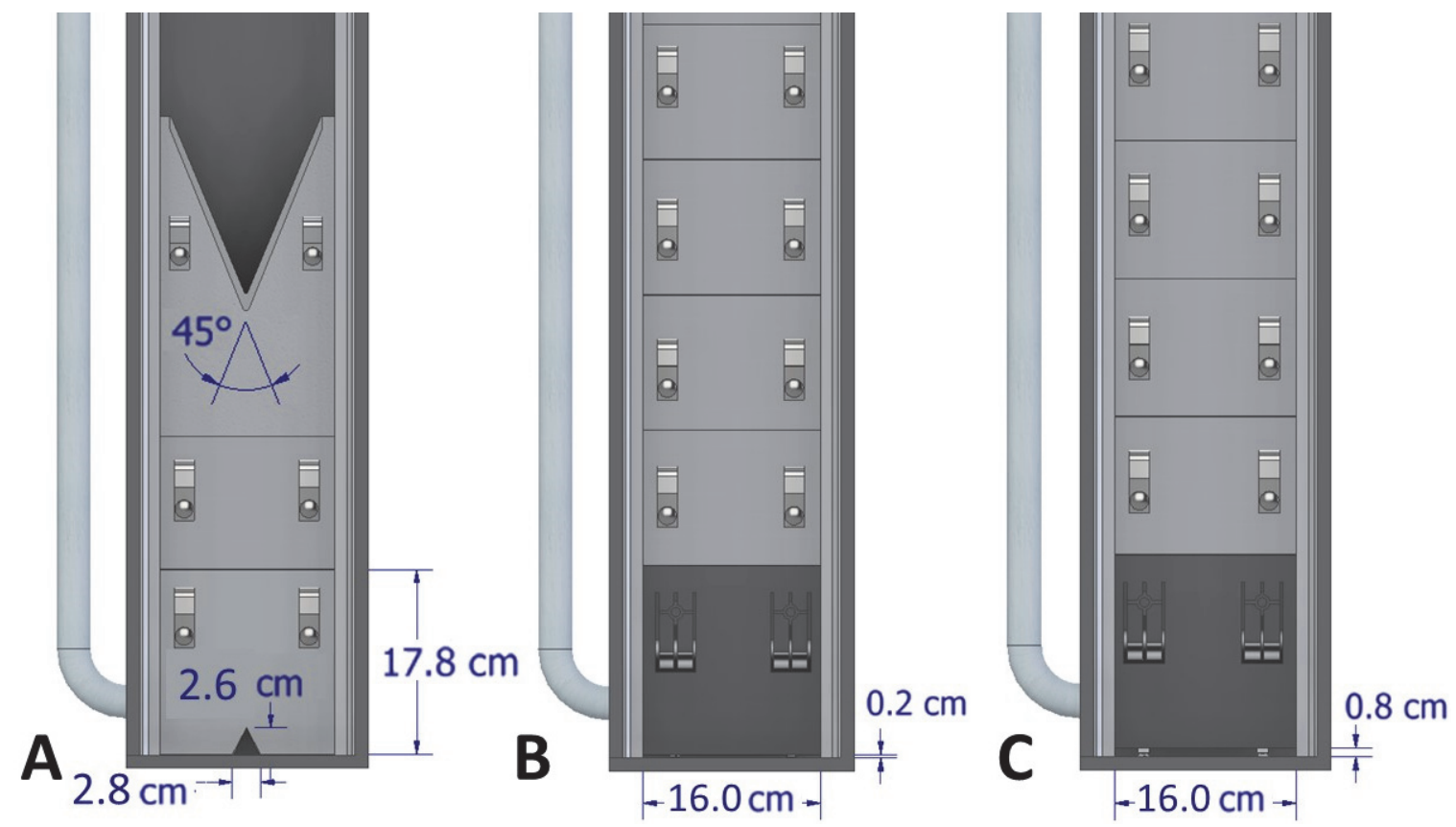

Figure 1. Drawings and dimensions of the three drawdown configurations tested. An inverted-v orifice plate (A) was tested in conjunction with a stainless steel-edged v-notch weir. Two rectangular orifices $2 \mathrm{~mm}(\mathrm{~B})$ and $8 \mathrm{~mm}(\mathrm{C})$ in height were made by lifting the stop log off the bottom of the control structure. 
NRCS (fig. 1a). This inverted-v was located at the base of the plate measuring $2.8 \mathrm{~cm}$ in width and $2.6 \mathrm{~cm}$ in height. This drawdown plate had previously been used at several monitored NRCS-designed bioreactors to prevent prolonged saturated conditions, but the stage-discharge relationship for this plate had not been established. These field bioreactors also used a v-notch stainless steel-edged weir to measure bioreactor outflow, for which the stage-discharge relationship was previously developed (Christianson et al., 2019). Stagedischarge for the inverted-v orifice was measured by placing the plate at the base of the control structure, a $12.7 \mathrm{~cm}$ stop $\log$ (standard AgriDrain 5 in.) on top of the bottom stop log, and finally the v-notch stainless steel-edged weir plate as the uppermost stop log (fig. 1). This was the configuration used in several monitored NRCS woodchip bioreactors. Flow measurements for the inverted-v plate were also taken under flooded conditions to mimic water level conditions frequently seen in field bioreactors, where the flow capacity of the tile drain downstream of the water level control structure is exceeded, raising the water level within the control structure. To mimic these conditions, water level downstream of the inverted-v plate was artificially raised by placing an additional water level control structure at the outlet of the control structure containing the inverted-v plate, with stop logs in the downstream structure raised to a height of $30 \mathrm{~cm}$.

Two additional drawdown configurations with rectangular orifices were also tested (figs. 1b and c) which simply raised the bottom stop log off the base of the control structure to allow flow to pass underneath the bottom stop log. These drawdown configurations with rectangular orifice were held off the base of the control structure using a screw and nut to adjust to the desired height. For these configurations, an unmodified AgriDrain stop log was raised to create a 2 and $8 \mathrm{~mm}$ gap above the control structure bottom, with AgriDrain stop logs placed on top of the drawdown plate up to a height of $60 \mathrm{~cm}$. Due to the design of the base of the water level control structure, the drawdown orifice in each configuration was always fully submerged with water level downstream of the stop logs above the top of the orifice.

Stage-discharge relationships were fitted to the equation for flow through an orifice (eq. 1), which is described as:

$$
Q=C_{C} * A^{*} \sqrt{2^{*} g^{* h}}
$$

where

$Q=$ flow through the orifice,

$C_{c}=$ contraction coefficient,

$A=$ orifice area,

$\mathrm{g}=$ gravitational acceleration constant, and

$\mathrm{h}=$ water head difference from upstream to downstream of the drawdown plate.

For the inverted-v plate, this equation was coupled with the previously developed equation for the stainless steeledged v-notch weir (Christianson et al., 2019) once water level was above the lowest point of the v-notch weir (i.e., the bottommost vertex of the v-notch). The equation for flow over the v-notch weir took the form of equation 2, where Christianson et al. (2019) determined a and b coefficients of 0.011 and 2.28, with $\mathrm{Q}$ in $\mathrm{L} \mathrm{s}^{-1}$ and $\mathrm{h}$ as the height of water above the bottommost vertex of the v-notch in $\mathrm{cm}$.

$$
Q=a h^{b}
$$

For the 2 and $8 \mathrm{~mm}$ gap configurations, the width of the rectangular orifice was measured as the space between the stop log metal brackets on either side of the control structure $(16.0 \mathrm{~cm})$, rather than the full width of the control structure $(20.5 \mathrm{~cm})$.

Fitting of equations 1 and 2 was done in $\mathrm{R}$ using the nls() function (R Core Team, 2020), which is used for finding the weighted least-squares estimates of the parameters of a nonlinear model. This method was used to determine values of $\mathrm{C}_{\mathrm{C}}$ for equation 1 for each drawdown configuration separately, and $\mathrm{a}$ and $\mathrm{b}$ coefficients for equation 2 for the v-notch weir. When fitting equation 1 , a constant value of $C_{C}$ was assumed over the range of water levels tested. The fitted equations 1 and 2 were used to obtain predicted values for flow based on head difference across the drawdown plate.

\section{RESULTS AND DISCUSSION}

Flow through each of the drawdown configurations was well-described by the orifice equation (fig. 2, Supplemental Information). After fitting the flow data to equation $1, \mathrm{R}^{2}$ of observed flow rates versus flow rates predicted by the fitted equation 1 were $>0.99$ for all three orifices. The $2 \mathrm{~mm}$ gap configuration had the lowest flow rates for a given head difference. The $8 \mathrm{~mm}$ gap configuration had the largest flow rates at a given head difference due to the larger orifice area $\left(12.3 \mathrm{~cm}^{2}\right)$ relative to the rectangular orifice made by the $2 \mathrm{~mm}$ gap $\left(2.6 \mathrm{~cm}^{2}\right)$. The stage-discharge relationship for the inverted-v drawdown plate was comparable to the $2 \mathrm{~mm}$ gap configuration, likely due to the similar area of the inverted$\mathrm{v}$ orifice $\left(3.6 \mathrm{~cm}^{2}\right)$. At a head difference $\sim 0.45 \mathrm{~m}$, the inverted-v plate and $2 \mathrm{~mm}$ gap configuration had flow rates of $0.81 \pm 0.01$ (mean \pm standard deviation) and $0.57 \pm 0.01 \mathrm{~L} \mathrm{~s}^{-1}$, respectively.

Water level downstream of the drawdown plates did not vary substantially over the range of flow rates tested. Downstream water level ranged from 7.5 to 9.0, 7.2 to 8.7, and 8.8 to $11.5 \mathrm{~cm}$ above the bottom of the control structure for the inverted-v, $2 \mathrm{~mm}$ gap, and $8 \mathrm{~mm}$ gap configurations, respectively. Flow through each of the drawdown configurations did not cover the full range of potential flow for the water level control structure, but rather covered the typical range of water level and head difference at the outlet of field bioreactors. Chun and Cooke (2008) tested flow rates over flat weirs up to $6 \mathrm{~L} \mathrm{~s}^{-1}$ in the same size water level control structure, indicating the tested orifice flow rates were below the flow capacity of the structure.

Values of the $\mathrm{C}_{\mathrm{C}}$ contraction coefficients were $0.74,0.74$, and 0.76 for the inverted-v drawdown plate, $2 \mathrm{~mm}$ gap, and $8 \mathrm{~mm}$ gap configurations, respectively (table 1 ). Under conditions where the downstream water level was raised $30 \mathrm{~cm}$ using a second water level control structure, the stage-discharge relationship for the inverted-v plate was not substantially different than when downstream water level was not raised, giving a $C_{c}$ value of 0.72 . Values of $C_{C}$ were higher than conventional values for flow through sharp-crested orifice $(\sim 0.61)$. Higher $C_{C}$ values reported here may have been 

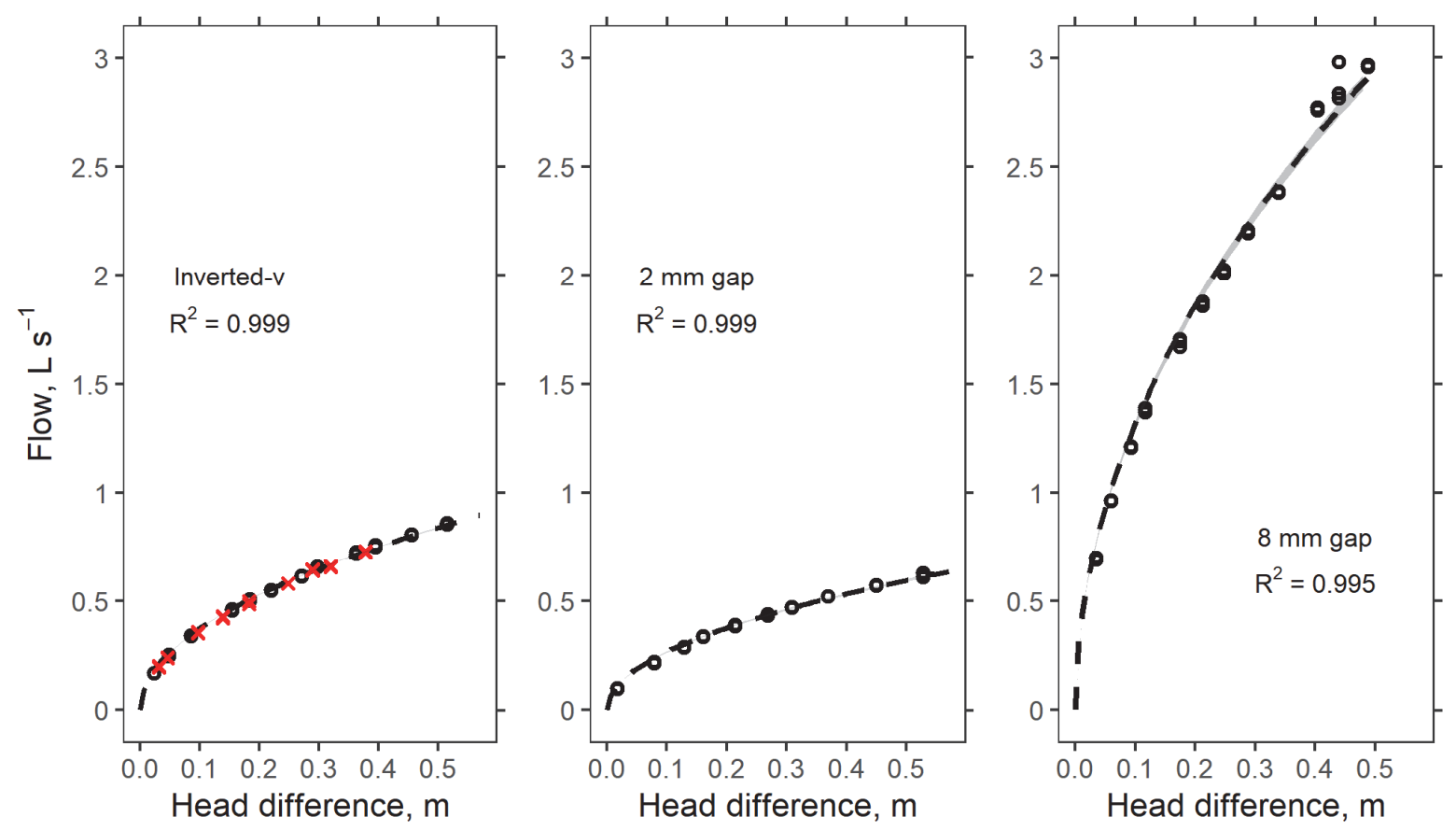

Figure 2. Stage-discharge relationships for the three drawdown plates. $\mathbf{R}^{2}$ values indicate the correlation between observed flow rates (hollow black circles) and predicted flow rates (dashed black line) given by the fitted equation 1 for each plate. Red $\times$ symbols for inverted-v indicate measurements taken under conditions where downstream water level was raised to $30 \mathrm{~cm}$. In all cases the drawdown orifice was fully submerged.

due to turbulence of flow produced as water exited the $15.2 \mathrm{~cm}$ diameter corrugated plastic tube and entered the control structure. Previous studies have shown that $\mathrm{C}_{\mathrm{C}}$ can increase as Reynold's number increases when flow is less laminar (Sahin and Ceyhan, 1996; Abd et al., 2019). The contraction coefficient for the $8 \mathrm{~mm}$ gap configuration was higher than that of the $2 \mathrm{~mm}$ gap by more than two standard errors, despite the same orifice shape with the only difference in the two configurations being the height of the stop $\log$ off the base of the control structure. This variation in calculated $\mathrm{C}_{\mathrm{C}}$ may be due to the uncertainty when measuring the area of the two rectangular orifices. An error of only 0.1 $\mathrm{mm}$ in the height of the rectangular orifice resulted in a change in calculated $\mathrm{C}_{\mathrm{C}}$ of 0.04 and 0.01 for the $2 \mathrm{~mm}$ and 8 $\mathrm{mm}$ gap plates, respectively. The $2 \mathrm{~mm}$ gap orifice was more sensitive to small measurement error in height of the orifice, which should be taken into account when making relative comparisons between the two rectangular orifices. The same measurement error of $0.1 \mathrm{~mm}$ for either dimension of the inverted-v orifice resulted in a change in $\mathrm{C}_{\mathrm{C}}$ of $<0.01$. That calculated $C_{C}$ values for all three orifices were within 0.02 of each other suggests that an assumed $C_{C}$ value within the range of 0.74 to 0.76 may be accurate for orifices in the $15.2 \mathrm{~cm}$ AgriDrain control structure.

These equations were developed in an AgriDrain water level control structure made for $15.2 \mathrm{~cm}$ (6 in.) nominal tile diameter. The $15.2 \mathrm{~cm}$ AgriDrain water level control structure was selected as this is the most common control structure size used at the outlet for field bioreactors where the drawdown plate is placed. Orifice area created by the $2 \mathrm{~mm}$ and $8 \mathrm{~mm}$ gap configurations would increase in larger water level control structures with wider stop logs, while the orifice area for the inverted-v drawdown plate would remain unchanged as it provides fixed area regardless of stop log width. It is possible that values for $\mathrm{C}_{\mathrm{C}}$ may differ in larger structures if structure size affects flow turbulence, and subsequently the Reynold's number, as flow enters the structure and moves through the orifice. Combining the contraction coefficients and the orifice area for each plate, the stage-discharge relationships for the inverted-v drawdown plate, $2 \mathrm{~mm}$ gap, and $8 \mathrm{~mm}$ gap configurations were $\mathrm{Q}=$ $3.26 * \mathrm{~A} * \mathrm{~h}^{0.5}, \mathrm{Q}=3.29 * \mathrm{~A} * \mathrm{~h}^{0.5}$, and $\mathrm{Q}=3.38 * \mathrm{~A} * \mathrm{~h}^{0.5}$, respectively, where $\mathrm{Q}$ is in $\mathrm{m}^{3} \mathrm{~s}^{-1}, \mathrm{~A}$ is the orifice area in $\mathrm{m}^{2}$ (table 1 , in $\mathrm{cm}^{2}$ ), and $\mathrm{h}$ is the water head differential in meters.

The combined inverted-v orifice and stainless steel-edged v-notch weir configuration performed as expected, with the stage-discharge relationship changing once water level reached the crest of the v-notch weir (fig. 3). Once flow crested the v-notch weir, total flow through the control structure was a sum of flow through the inverted-v orifice and over the v-notch weir. Flow over the v-notch weir was calculated by subtracting the flow predicted by the fitted equation for the inverted-v orifice (eq. 1, table 1) at the given head difference from total measured flow through the control

Table 1. Values of the contraction coefficient $\left(C_{C}\right)$ for each of the drawdown plates after fitting the stage-discharge relationship to equation 1 . $^{\text {[a] }}$

\begin{tabular}{|c|c|c|c|c|c|}
\hline Orifice & $\begin{array}{l}\text { Area } \\
\left(\mathrm{cm}^{2}\right)\end{array}$ & $\mathrm{C}_{\mathrm{C}}$ & $\begin{array}{c}\mathrm{C}_{\mathrm{C}} \\
\text { Standard } \\
\text { Error }\end{array}$ & $\mathrm{R}^{2}$ & $\begin{array}{c}\text { Residual } \\
\left(\mathrm{L} \mathrm{s}^{-1}\right)\end{array}$ \\
\hline Inverted-v & 3.6 & 0.74 & 0.002 & 0.999 & 0.01 \\
\hline $2 \mathrm{~mm}$ gap & 2.6 & 0.74 & 0.004 & 0.999 & 0.01 \\
\hline $8 \mathrm{~mm}$ gap & 12.3 & 0.76 & 0.005 & 0.995 & 0.05 \\
\hline
\end{tabular}

[a] Includes the standard error of prediction for $\mathrm{C}_{\mathrm{C}}$, the $\mathrm{R}^{2}$ value of observed versus predicted flow rates, and the residual error of the fitted equation. 

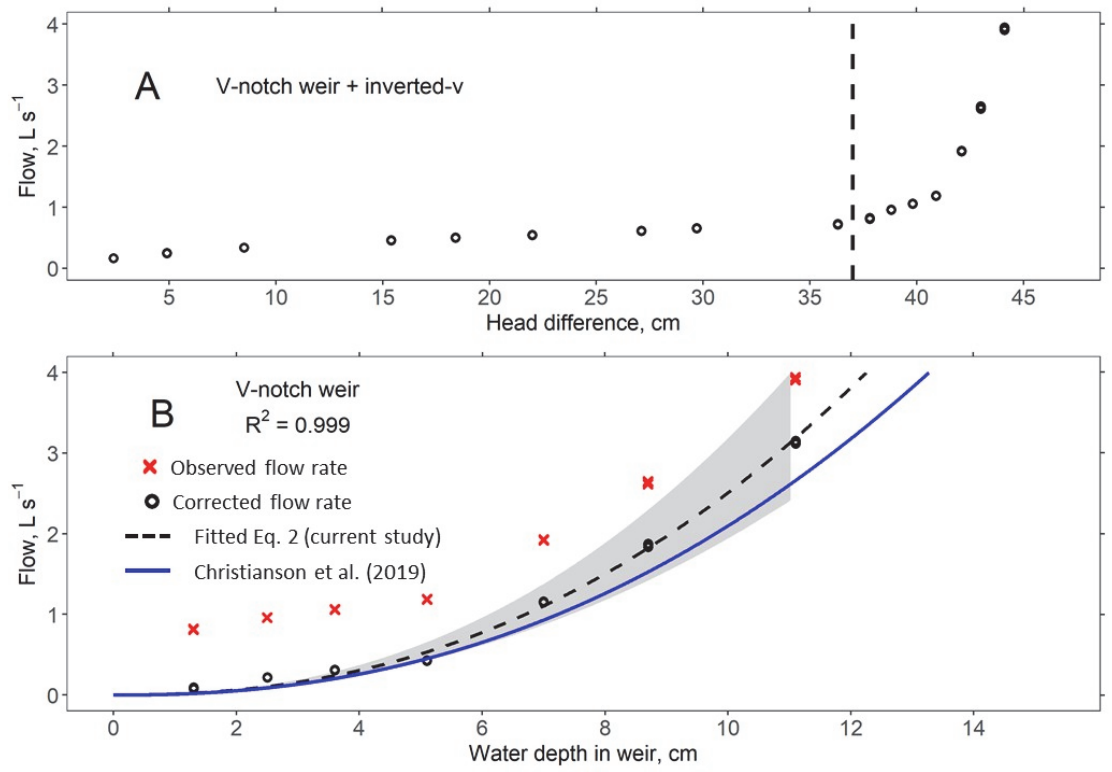

Figure 3. Observed flow rates for the combined inverted-V orifice stop log and stainless steel-edged v-notch weir configuration (A), where vertical dashed line indicates the height at which water level crested the v-notch weir. The stage-discharge relationship for the stainless steel-edged $v$ notch weir only (B). Red $\times$ symbols indicate the observed flow rates, while black hollow circles indicate the corrected flow rates for the v-notch weir after subtracting the predicted flow for inverted-v orifice based on equation 1 . The fitted equation 2 is indicated by the dashed black line, with $95 \%$ prediction interval shown in gray. Blue solid line indicates the previously reported relationship for the stainless steel-edged v-notch weir (Christianson et al., 2019).

structure. This resulted in estimates for the $a$ and $b$ coefficients (eq. 2) of $0.013 \pm 0.001$ (estimate \pm standard error) and $2.30 \pm 0.03$, respectively. Flow over the stainless steel-edged $\mathrm{v}$-notch weir was given by $\mathrm{Q}=0.013 * \mathrm{~h}^{2.30}$, where $\mathrm{Q}$ is in $\mathrm{L}$ $\mathrm{s}^{-1}$ and $\mathrm{h}$ is depth of water in the weir in $\mathrm{cm}$. The calculated $b$ coefficient was within one standard error of the $b$ coefficient previously reported for this stainless steel-edged $\mathrm{v}$ notch weir $(a=0.011, b=2.28)$ when aggregating data collected at different weir heights and control structure sizes, while the calculated a coefficient in this study was within the range of values (a 0.010-0.017; b 2.14-2.27) calculated when separating data sets by treatment (Christianson et al., 2019). The aggregated weir relationship equation reported in Christianson et al. (2019) fits within the 95\% prediction interval based on coefficients calculated in this study.

This small difference in coefficient values for equation 2 was likely not due to the curve-fitting method. The nls() function in $\mathrm{R}$ used in this article, when applied to the previously collected stage-discharge data for this weir, calculated the same coefficients as Christianson et al. (2019). Difference in coefficients may have been due to error introduced when subtracting predicted flow through the inverted-v orifice (based on fitted eq. 1) from total measured flow to estimate flow over the v-notch weir for fitting equation 2 . The calculated coefficients of equation 2 were also sensitive to measurement error for height of the weir. A difference of only $1 \mathrm{~mm}$ in the height of the bottom-most vertex of the $\mathrm{v}$ notch weir above the bottom of the control structure resulted in a 0.001 and 0.02 change in values for $a$ and $b$ coefficients, respectively. Unlike the current study, the previous study did not calibrate the load cell with known weights immediately prior to flow measurements. Considering, however, both coefficients in this study fell within the range or standard error of calculated values in Christianson et al., it is likely the load cell calibration was not largely different. This study could not conclude that the inverted-v drawdown plate, used in combination with the v-notch weir in the configuration tested in this study, significantly changed the stage-discharge relationship for this stainless steel-edged v-notch weir as previously established. This result suggests the same should be applicable to other previously tested AgriDrain weir configurations (Chun and Cooke, 2008). Accurate monitoring of flow in field bioreactors can be achieved when using a drawdown plate, as long as the flow through the lowlevel orifice is included.

Stage-discharge relationships for the orifice plates can be used to estimate the length of time needed to drain a woodchip bioreactor of given size. Lab and field studies indicate that methane and sulfide production does not occur until HRT is on the order of days (Lepine et al., 2016; Malá et al., 2020; Rivas et al., 2020), although the occurrence of highly reduced conditions also depends on water temperature and chemistry (e.g., nitrate concentration, dissolved oxygen, oxidation reduction potential). A target drawdown time of 24 to $36 \mathrm{~h}$ could be considered practical for draining the bioreactor within a reasonable time. The USDA NRCS Conservation Practice Standard for denitrifying bioreactors recommends a drawdown time no greater than $48 \mathrm{~h}$. For example, for a $4 \times 15 \mathrm{~m}$ bioreactor with a stagnant water level of $1 \mathrm{~m}$, assuming a drainable porosity of 0.5 for the woodchip media (Robertson, 2010; Ghane et al., 2014), the inverted-v plate, $2 \mathrm{~mm}$ gap, and $8 \mathrm{~mm}$ gap configurations would lower the water level in the bioreactor to a height of $2 \mathrm{~cm}$ within 12,17 , and $4 \mathrm{~h}$, respectively.

It is important to select a drawdown configuration that does not affect hydraulic functioning of the bioreactor during design flow rates. The orifice should be sized such that flow through the orifice at the outlet stop log setting does not 
exceed the design flow rate for the bioreactor when the bed is fully saturated. If flow through the woodchip media is assumed to approximately follow Darcy's Law for flow through saturated media, outflow from the bioreactor should follow equation 3 .

$$
Q=k * \frac{\Delta h}{L} * A
$$

where

$k=$ saturated hydraulic conductivity of the woodchips,

$\Delta \mathrm{h}=$ head difference across the bioreactor,

$L=$ bioreactor length, and

$A=$ cross-sectional area perpendicular to flow.

For proper design, orifice flow through the drawdown opening should not exceed the design flow rate in equation 3. Setting equations 1 and 3 equal, assuming the invert of the outlet control structure as the datum, the maximum allowable orifice area to prevent these conditions would be:

$$
\begin{aligned}
& A_{\text {orifice }}= \\
& 0.113 * \frac{k^{*}\left(h_{\text {inlet }}-h_{\text {outlet }, 1}\right) *\left(h_{\text {inlet }}+h_{\text {outlet }, 1}\right) * W}{C_{C} * L^{*} \sqrt{h_{\text {outlet }, 1}-h_{\text {outlet }, 2}}}
\end{aligned}
$$

where

$$
\begin{aligned}
A_{\text {orifice }}= & \text { orifice area, } \\
h_{\text {inlet }}= & \text { water level in the bioreactor inlet control } \\
& \text { structure, } \\
h_{\text {outlet }, 1}= & \text { water level at the bioreactor outlet on upstream } \\
& \text { side of stop logs, } \\
h_{\text {outlet }, 2=} & \text { water level at the bioreactor outlet on downstream } \\
& \text { side of stop logs, and } \\
W \quad & \text { bioreactor width. }
\end{aligned}
$$

Values of saturated hydraulic conductivity range between 2 and $7 \mathrm{~cm} \mathrm{~s}^{-1}$ in woodchip bioreactors (Chun et al., 2010; David et al., 2016), and values of the contraction coefficient calculated in this study were $0.74-0.76$. Water level downstream of the drawdown plate may depend on site specific outlet conditions, with water level varying by $<3 \mathrm{~cm}$ over the flow rates tested in this study. At orifice area values greater than the value in equation 4, the observed HRT would be shorter than the design HRT as orifice flow exceeds design flow rate, likely affecting nitrate removal efficiency. In the previous example of a $4 \times 15 \mathrm{~m}$ bioreactor, the $4 \mathrm{~h}$ time to drain for the $8 \mathrm{~mm}$ gap configuration may be too close to the design HRT and provide too large an orifice. Use of equation 4 for field bioreactors should consider that water head in the inlet and outlet structure would be marginally different than the head difference across the bioreactor $(\Delta \mathrm{h}$ in eq. 3$)$ due to head losses that occur when water moves across the wall of corrugated plastic tubing (Mohammad and Skaggs, 1983) typically used for bioreactor flow distributors.

For some field bioreactors, the pipe downstream of the bioreactor outlet control structure may not drain as quickly as expected. It is important to remember to use the head difference upstream and downstream of the drawdown plate rather than the water level height upstream of the orifice. Under flooded conditions in the field (i.e., when flow capac- ity of the outlet tile line is exceeded), flow through the drawdown plate will be overestimated if only water level upstream of the orifice is measured since the actual water head differential across the plate is less than the upstream water depth.

\section{CONCLUSIONS}

Drawdown configurations are an inexpensive method for gravity-draining the woodchip bioreactor media during periods of no flow or low flow to avoid methane and sulfide reduction and do not require additional labor by the farmer to manage water level. Calibrated flow equations for the inverted-v plate, $2 \mathrm{~mm}$ gap, and $8 \mathrm{~mm}$ gap in the water level control structure $(15.2 \mathrm{~cm}$ nominal tile size $)$ were $\mathrm{Q}=$ $3.26 * \mathrm{~A} * \mathrm{~h}^{0.5}, \mathrm{Q}=3.29 * \mathrm{~A} * \mathrm{~h}^{0.5}$, and $\mathrm{Q}=3.38 * \mathrm{~A} * \mathrm{~h}^{0.5}$, respectively, where $\mathrm{Q}$ is in $\mathrm{m}^{3} \mathrm{~s}^{-1}, \mathrm{~A}$ is the orifice area in $\mathrm{m}^{2}$ (table 1 , in $\mathrm{cm}^{2}$ ), and $\mathrm{h}$ is the water head differential in $\mathrm{m}$. When these configurations are used, the stage-discharge relationships should be combined with calculated flow over the weir in control structures to accurately measure total flow through the bioreactor. Conservative sizing of the drawdown orifice should be used, such that drawdown rates by the orifice do not affect HRT and nitrate removal performance during design flow conditions.

\section{ACKNOWLEDGEMENTS}

The authors would like to thank the Department of Agricultural and Biological Engineering for use of the Hydraulics Lab. Drawings of the orifice stop logs and control structures were provided by Charles Dochoff. Assistance with experimental set-up and data collection was provided by Falasy Anamalechi. The following sources provided funding for this research to occur: USDA Hatch Project ILLU-802-925, USDA-NRCS NR185A12XXXXC004 CESU under the Great Rivers Umbrella Agreement 683A75-18-504, and Illinois Nutrient Research and Education Council Project \#2017-4-360498-302.

\section{SUPPLEMENTAL INFORMATION}

Table with height of water in the control structure upstream and downstream of the drawdown plate, head difference across the plate, and measured flow rate. Data can be found at https://doi.org/10.13031/16567494.

\section{REFERENCES}

Abd, H. M., Alomar, O. R., \& Mohamed, I. A. (2019). Effects of varying orifice diameter and Reynolds number on discharge coefficient and wall pressure. Flow Meas. Instrum., 65, 219-226. https://doi.org/10.1016/j.flowmeasinst.2019.01.004

Christianson, L. E., Christianson, R. D., Lipka, A. E., Bailey, S., Chandrasoma, J., McCoy, C., ... Cooke, R. A. (2019). Calibration of stainless steel-edged v-notch weir stop logs for water level control structures. Appl. Eng. Agric., 35(5), 745-749. https://doi.org/10.13031/aea.13350

Chun, J. A., \& Cooke, R. A. (2008). Technical note: Calibrating agridrain water level control structures using generalized weir and orifice equations. Appl. Eng. Agric., 24(5), 595-602. https://doi.org/10.13031/2013.25274 
Chun, J. A., Cooke, R. A., Eheart, J. W., \& Cho, J. (2010). Estimation of flow and transport parameters for woodchip-based bioreactors: II. field-scale bioreactor. Biosyst. Eng., 105(1), 95102. https://doi.org/10.1016/j.biosystemseng.2009.09.018

Davis, M. P., Martin, E. A., Moorman, T. B., Isenhart, T. M., \& Soupir, M. L. (2019). Nitrous oxide and methane production from denitrifying woodchip bioreactors at three hydraulic residence times. J. Environ. Manag., 242, 290-297. https://doi.org/10.1016/j.jenvman.2019.04.055

Ghane, E., Fausey, N. R., \& Brown, L. C. (2014). Non-Darcy flow of water through woodchip media. J. Hydrol., 519, 3400-3409. https://doi.org/10.1016/j.jhydrol.2014.09.065

Kinsman-Costello, L. E., O'Brien, J. M., \& Hamilton, S. K. (2015). Natural stressors in uncontaminated sediments of shallow freshwaters: The prevalence of sulfide, ammonia, and reduced iron. Environ. Toxicol. Chem., 34(3), 467-479. https://doi.org/10.1002/etc. 2801

Lepine, C., Christianson, L., Sharrer, K., \& Summerfelt, S. (2016). Optimizing hydraulic retention times in denitrifying woodchip bioreactors treating recirculating aquaculture system wastewater. JEQ, 45(3), 813-821. https://doi.org/10.2134/jeq2015.05.0242

Mala, J., Hrich, K., Schrimpelova, K., \& Bilkova, Z. (2020). Production of sulphides in denitrifying woodchip bioreactors. Environ. Sci. Pollution Res., 27(32), 40769-40776. https://doi.org/10.1007/s11356-020-10089-4

Mohammad, F. S., \& Skaggs, R. W. (1983). Drain tube opening effects on drain inflow. J. Irrig. Drain. Eng., 109(4), 393-404. https://doi.org/10.1061/(ASCE)0733-9437(1983)109:4(393)
R Core Team. (201). R: A language and environment for statistical computing. Vienna, Austria: R Foundation for Statistical Computing. Retrieved from https://www.R-project.org/

Rivas, A., Barkle, G., Stenger, R., Moorhead, B., \& Clague, J. (2020). Nitrate removal and secondary effects of a woodchip bioreactor for the treatment of subsurface drainage with dynamic flows under pastoral agriculture. Ecol. Eng., 148, 105786. https://doi.org/10.1016/j.ecoleng.2020.105786

Robertson, W. D. (2010). Nitrate removal rates in woodchip media of varying age. Ecol. Eng., 36(11), 1581-1587. https://doi.org/10.1016/j.ecoleng.2010.01.008

Sahin, B., \& Ceyhan, H. (1996). Numerical and experimental analysis of laminar flow through square-edged orifice with variable thickness. Trans. Inst. Measurement Control, 18(4), 166-174. https://doi.org/10.1177/014233129601800401

Schipper, L. A., Robertson, W. D., Gold, A. J., Jaynes, D. B., \& Cameron, S. C. (2010). Denitrifying bioreactors-An approach for reducing nitrate loads to receiving waters. Ecol. Eng., 36(11), 1532-1543. https://doi.org/10.1016/j.ecoleng.2010.04.008

Shih, R., Robertson, W. D., Schiff, S. L., \& Rudolph, D. L. (2011). Nitrate controls methyl mercury production in a streambed bioreactor. JEQ, 40(5), 1586-1592. https://doi.org/10.2134/jeq2011.0072

USDA NRCS Illinois. (2020). Conservation Practice Standard Denitrifying Bioreactor Code 605 (605-CPS). Champaign, IL: USDA NRCS.

Warneke, S., Schipper, L. A., Bruesewitz, D. A., McDonald, I., \& Cameron, S. (2011). Rates, controls and potential adverse effects of nitrate removal in a denitrification bed. Ecol. Eng., 37(3), 511-522. https://doi.org/10.1016/j.ecoleng.2010.12.006 